\title{
Antioxydant response to biotic and abiotic inducers for the resistance against fusarium wilt disease in eggplant (Solanum melongena L.)
}

\author{
Hacer H. AltinoK ${ }^{1 *}$, Murat Dikilitas ${ }^{2}$ \\ ${ }^{1}$ Erciyes University, Faculty of Agriculture, Department of Plant Protection, Kayseri, Turkey \\ ${ }^{2}$ Harran University, Faculty of Agriculture, Department of Plant Protection, Sanliurfa, Turkey
}

\begin{abstract}
Acibenzolar-S-methyl as an abiotic plant activator and a non-host isolate of Fusarium oxysporum on eggplant (F. oxysporum f. sp. melonis) as a biotic inducer were applied to eggplant seedlings in order to confer increased resistance to $F$. oxysporum $\mathrm{f}$. sp. melongenae, the causal agent of Fusarium wilt of eggplant. Acibenzolar-S-methyl and $F$. oxysporum f. sp. melonis were applied $72 \mathrm{~h}$ before pathogen inoculation and the development of disease symptoms was assessed with a Fusarium yellow rating at $7^{\text {th }}, 11^{\text {th }}, 14^{\text {th }}, 17^{\text {th }}$ and $21^{\text {th }}$ day after inoculation. Pretreatment of eggplants with Acibenzolar-S-methyl and $F$. oxysporum f. sp. melonis significantly reduced the severity of Fusarium wilt disease. The severity of the disease in positive control plants reached to $92.50 \%$ whereas that of acibenzolar-S-methyl and F. oxysporum f. sp. melonis-pretreated seedlings of eggplants was only $32.21 \%$ and $21.13 \%$, respectively, 21 days after inoculation. Acibenzolar-S-methyl and $F$. oxysporum $\mathrm{f}$. sp. melonis pretreatments resulted in a hypersensitive reaction and triggered the elaboration of histological barriers such as callose and $\mathrm{H}_{2} \mathrm{O}_{2}$ synthesis. In situ studies demonstrated that the hydrogen peroxide $\left(\mathrm{H}_{2} \mathrm{O}_{2}\right)$ accumulation and the callose deposition as responses to the pathogen attack started $24 \mathrm{~h}$ after inoculation. Acibenzolar-S-methyl and F. oxysporum f. sp. melonis-pretreated plants also showed significant increases in the activity of catalase and polyphenol oxidase enzymes along with the increase of proline and $\mathrm{H}_{2} \mathrm{O}_{2}$ content when compared to $F$. oxysporum f. sp. melongenae-infected plants.
\end{abstract}

Keywords: Acibenzolar-S-methyl, catalase, fusarium wilt disease, Fusarium oxysporum, hydrogen peroxide, induced resistance, polyphenol oxidase, Solanum melongena

\begin{abstract}
Abbreviations: ASM - acibenzolar-S-methyl, DAI - days after inoculation, CAT catalase, PPO - polyphenol oxidase, FOM - Fusarium oxysporum f. sp. melonis, Fomg Fusarium oxysporum f. sp. melongenae, $\mathbf{H R}$ - hypersensitive reaction
\end{abstract}

* Corresponding author, e-mail: ahandan@gmail.com

Copyright $^{\circledR} 2014$ by Acta Botanica Croatica, the Faculty of Science, University of Zagreb. All rights reserved. 


\section{Introduction}

Fusarium wilt caused by Fusarium oxysporum Schlecht. f. sp. melongenae (Fomg) is an economically important soil-borne disease limiting eggplant production worldwide. This pathogen is one of the most important fungal pathogens of eggplants (Solanum melongena) in the Mediterranean region of Turkey, which causes serious yield losses. Infected plants exhibit leaf chlorosis and slight vein clearing on outer leaflets initially, then yellowing and leaf-dropping, followed finally by vascular discoloration of stem and death of aboveground portions (ALTINOK 2005). Current strategies for the control of this disease are based mostly on soil disinfection, use of resistant cultivars and efficient fungicides. The most effective method for control of the disease worldwide has been suggested to be the use of resistant cultivars; however, no variety so far has been reported as being resistant to Fomg. Although physiological races of this pathogen have not been reported, however, only one vegetative compatibility group (VCG) has been identified (KATAN 1999, ALtinOK and CAN 2010). A pathogenic strain applied to a non-host plant is able to protect it against further infection by its specific formae speciales, which is a well-established phenomenon and has been described as cross-protection or premonition (MATTA 1989). This phenomenon is known as an expression of induced systemic resistance (ISR), a defense mechanism of plant response to microbial infections. Plants exhibit a wide variety of defense strategies against pathogen attack. They form physical barriers and biochemical defenses before and after pathogen attacks. However, barriers formed depend on the ability and structure of the plants rather than the severity of the pathogen (DIKILITAS 2003). For example, a type of plant defense system such as hypersensitive response (HR), also called plant cell death, due to host-pathogen incompatibility prevents crop plants from pathogen infection (MEHDY 1994). Systemic acquired resistance (SAR) is another defense mechanism which plays an important role in protecting plants from pathogen attack and this mechanism is often accompanied by HR (HAMMERSCHMIDT and KUC 1995). The responses of induced resistance in plants can be activated by using biotic inducers or by some chemicals such as acibenzolar-S-methyl (BTH or ASM), salicylic acid (SA), and 2,6-dichloroisonicotinic acid (INA) (GRAHAM and GRAHAM 1999). ASM as a potential plant activator has no antimicrobial activity but it activates the SAR signal transduction pathway against a broad spectrum of fungal, bacterial and viral pathogens in many plants (IsHII et al. 1999). Induced resistance needs an inducer prior to the pathogen attack; however, the time between the inducer and challenger inoculation is an important factor for the development of induced resistance; it ranges from one to three days for Fusarium wilt diseases (MATTA 1989).

The induction of SAR is related to various cellular defense responses which are a synthesis of pathogenesis-related proteins (PR), phytoalexins, localized cell death, the accumulation of wall-bound phenolic compounds and synthesis of hydrolytic enzymes such as chitinase, $\beta$-1,3-glucanase and peroxidase (DIKILITAS et al. 2009). The characteristics of HR include rapid generation of active oxygen species (AOS), described as the oxidative burst, which occurs in the early phase of plant-pathogen interactions. In this stage, $\mathrm{H}_{2} \mathrm{O}_{2}$ is formed as a signaling molecule, and is one of the main components of AOS. Apart from $\mathrm{H}_{2} \mathrm{O}_{2}$, superoxide $\left(\mathrm{O}_{2}^{-}\right)$and hydroxyl $(\mathrm{OH})$ radicals are also produced to protect the plants from attacking organisms (BORDEN and HigGins 2002). Accumulation of AOS in the organism contributes to the defense system as an antimicrobial compound, which helps to form cell wall barriers, and as a secondary signaling molecule to activate defense responses (DE GARA 
et al. 2003). For example, the generation of $\mathrm{H}_{2} \mathrm{O}_{2}$ results in the formation of lignin and callose; their deposition with proteins and phenolics at sites of penetration is recognized as an early defense response of a host to microbial pathogens (NICHOLSON and HAMMERSCHMIDT 1992, HAMMERSCHMIDT and KuC 1995, JACOBS et al. 2003). However, it should be remembered that the excess of AOS production can significantly damage plant tissues at structural and functional levels (DJEBALI et al. 2007). As a response to pathogen attack, plants are protected against the damage of reactive oxygen species by an antioxidant system which includes enzymes such as superoxide dismutase (SOD) and peroxidase (POD). For example, SOD activity has been shown to change in response to salt stress LEE et al. (2001) and to pathogen attack of plants DE GARA et al. (2003). Peroxidase activity in diseased plants was also observed to have resistance involved in many host-pathogen interactions (ALCAZAR et al. 1995).

The mechanisms involved in the induced resistance against Fomg have not been adequately studied. The purpose of the present study was to evaluate the potential plant activator ASM and a non-host Fusarium oxysporum f. sp. melonis strain for the inhibition of Fusarium wilt disease of eggplant caused by Fomg and to investigate their possible modes of action through changes in proline accumulation and in situ localization of $\mathrm{H}_{2} \mathrm{O}_{2}$ and callose, and changes in specific activity of the antioxidant enzymes such as catalase (CAT) and polyphenol oxidase (PPO).

\section{Materials and methods}

\section{Plant material}

Eggplant (Solanum melongena L. cv. »Kemer«, susceptible to Fomg) seeds were sterilized by being dipped in $1 \%$ sodium hypochlorite $(\mathrm{v} / \mathrm{v})$ for $30 \mathrm{~min}$ and sown in a soil mix containing sand, perlite, and peat compost $(1: 1: 2)$, and kept in a growth chamber $\left(25^{\circ} \mathrm{C}\right.$, $60-70 \% \mathrm{RH}, 12 \mathrm{~h}$ photoperiod, 50 to $60 \mathrm{Klux} \mathrm{m}^{-2}$ ). The eggplant seedlings were transplanted when they were 6 week old to pots $8.5 \mathrm{~cm}$ in diameter. The seedlings were then watered on demand and fertilized with NPK (15:15:15).

\section{The pretreatment of ASM and a non-host Fusarium oxysporum isolate on eggplants}

An abiotic plant activator, Acibenzolar-S-methyl (benzo [1, 2, 3] thiadiazole-7-carbothioic acid-S-methyl ester, ASM; Actigard 50 WG, Syngenta Crop Protection, Inc., Basel Switzerland) and the non-host fungus of the eggplant Fusarium oxysporum f. sp. melonis (FOM) as a biotic inducer were used in this study. Fusarium oxysporum f. sp. melongenae (Fomg), the most virulent isolate, according to the severity of the disease reported in a former study, was selected for pathogen inoculation (ALTINOK and CAN 2010). ASM was dissolved in distilled water to obtain a concentration of $0.2 \mathrm{mg} \mathrm{mL}^{-1}$ and then sprayed onto eggplant seedlings at 7-8 leaf stage. In parallel, a set of seedlings were pretreated with FOM by root-dipping into a conidial suspension of FOM $\left(10^{6}\right.$ conidia $\left.\mathrm{mL}^{-1}\right)$ for $10 \mathrm{~min}$. Seventy two hours after the pretreatments (ASM, FOM, or water), the seedlings were then dipped into the conidial suspension of the pathogen Fomg $\left(10^{6}\right.$ conidia $\left.\mathrm{mL}^{-1}\right)$ for $10 \mathrm{~min}$. Two Fusarium strains (the pathogen and the inducer) were cultured on Fusarium-minimal medium; for 7 days in the dark at $25{ }^{\circ} \mathrm{C}$ (NELSON et al. 1983). In the control set, the water- 
-treated plants (positive control) were dipped into the conidial inoculum of Fomg for the same time period. The healthy controls (negative control) were also treated with sterile distilled water instead of treatments. In our previous study, the optimum time interval for SAR induction was determined to be $72 \mathrm{~h}$ for these inducers (ALTINOK 2009). After the pathogen inoculation, the seedlings were transplanted into plastic pots and kept in the growth chamber as described above.

\section{Microscopy studies}

In order to detect early accumulation of $\mathrm{H}_{2} \mathrm{O}_{2}$ and callose deposition, the samples were examined 24, 48 and $72 \mathrm{~h}$ after inoculation. Samplings were then continued 7, 1, 14 and 21 days after inoculation. The fresh leaf tissues were immediately used for microscopic examination.

The microscopic examination of the infected plants was carried out on a microscope (Nikon Optiphot) equipped with differential interference contrast (DIC). The detection of callose accumulation during the infection is discussed by NICHOLSON and HAMMERSCHMIDT (1992), and HAMMERSCHMIDT and KUC (1995), referring to fluorescence microscopy and histochemical studies. Autofluorescence of the callose in infected tissue was detected with UV light irradiation (350-450 nm; excitation-emission). The cell-wall bound callose components fluoresced bright pale blue under UV light. The tissues were observed with 40X optic zoom and recorded with a digital camera (DP71; Olympus).

The accumulation of $\mathrm{H}_{2} \mathrm{O}_{2}$ was visualized using 3,3 N-Diaminobenzidine Tetrahydrochloride Liquid Substrate System (DAB; Sigma, St. Louis, USA). The infected leaves were incubated in a solution of DAB (1 mL of DAB Liquid Chromogen to $9 \mathrm{~mL}$ of DAB Liquid Buffer) for $20 \mathrm{~min}$ in the dark and the reaction was stopped by gentle washing of the leaf sample in water. The plant tissues were then transferred to $100 \%$ methanol and incubated overnight at room temperature to remove chlorophyll, followed by soaking in an aqueous solution saturated with chloral hydrate $\left(2.5 \mathrm{~g} \mathrm{~mL}^{-1}\right)$ for $12-24 \mathrm{~h}$ to soften and clear the tissue. The samples were subsequently mounted in $50 \%$ glycerol and a cover-slip placed over the samples to produce semi-permanent preparations. The accumulation of $\mathrm{H}_{2} \mathrm{O}_{2}$ appeared as dark brown pigmentation (SOYLU 2006).

The deposition of the callose substances in the leaves of infected plants was determined with the aniline blue fluorescence method. The infected leaves were incubated in a solution of $1 \%$ phloroglucinol in $100 \%$ methanol overnight at room temperature. Following further incubation for clearing tissues in chloral hydrate $\left(2.5 \mathrm{~g} \mathrm{~mL}^{-1}\right)$, they were then transferred to aniline blue $(0.05 \% \mathrm{w} / \mathrm{v})$ reagent prepared in sodium phosphate buffer $(1 \mathrm{M}, \mathrm{pH} 8.0)$. After this stage, the samples were mounted on slides with a few drops of Hoyer's solution $[30 \mathrm{~g}$ gum arabic (Sigma G-9752), $200 \mathrm{~g}$ chloral hydrate (Sigma C-8383), 20 g glycerol, $50 \mathrm{~mL}$ water], and the slides were covered with a coverslip for the microscopic examination (Bougourd et al. 2000).

\section{Sample preparation for enzymatic studies}

For enzyme analyses, leaf tissues were sampled 7, 14 and 21 days after inoculation (DAI). The leaf samples for enzyme analysis were stored at $-80{ }^{\circ} \mathrm{C}$ until use. 
A one-gram leaf sample was ground with an ice-cold pestle and mortar with $10 \mathrm{~mL} 50$ $\mathrm{mM}$ phosphate buffer ( $\mathrm{pH}$ 7.0). The homogenates were centrifuged at $12000 \mathrm{~g}$ for $20 \mathrm{~min}$ at $4{ }^{\circ} \mathrm{C}$. The supernatant filtered through two layers of the cheese-cloth was used for the assays of the enzymatic activities as well as for protein and $\mathrm{H}_{2} \mathrm{O}_{2}$ determination.

\section{Determination of $\mathrm{H}_{2} \mathrm{O}_{2}$ content}

The $\mathrm{H}_{2} \mathrm{O}_{2}$ content was measured colorimetrically after reaction with $\mathrm{TiCl}_{4}$ as described by TsAI et al. (2004) with slight modifications. The reaction mixture consisted of $1.8 \mathrm{~mL}$ of $50 \mathrm{mM}$ phosphate buffer ( $\mathrm{pH} 7.0), 0.2 \mathrm{~mL}$ of leaf extract supernatant and $1 \mathrm{~mL}$ reagent [0.1\% (v/v) $\mathrm{TiCl}_{4}$ in $\left.20 \%(\mathrm{v} / \mathrm{v}) \mathrm{H}_{2} \mathrm{SO}_{4}\right]$. The samples without leaf extract were used as blank. The absorbance was measured at $410 \mathrm{~nm}$. The amount of $\mathrm{H}_{2} \mathrm{O}_{2}$ was calculated by use of a standard curve prepared with known concentration of $\mathrm{H}_{2} \mathrm{O}_{2}$. The $\mathrm{H}_{2} \mathrm{O}_{2}$ content was expressed as $\mu \mathrm{mol} \mathrm{g}{ }^{-1}$ fresh weight (FW).

\section{Proline measurement}

The proline content was measured according to the method of BATES et al. (1973). Proline was extracted from $0.5 \mathrm{~g}$ of leaf sample by grinding in $10 \mathrm{~mL}$ of $3 \%$ sulphosalicylic acid and the mixture was centrifuged at $10000 \mathrm{~g}$ for $10 \mathrm{~min}$. Two $\mathrm{mL}$ of the supernatant was mixed with $2 \mathrm{~mL}$ freshly prepared acid-ninhydrin and $2 \mathrm{~mL}$ glacial acetic acid and heated at $90{ }^{\circ} \mathrm{C}$ in a water bath for $1 \mathrm{~h}$. The reaction was terminated in an ice-bath, and then $5 \mathrm{~mL}$ toluene was added to the mixture and vortexed for $15 \mathrm{sec}$. After standing at least $20 \mathrm{~min}$ in darkness at room temperature to separate the toluene and the aqueous phase, the toluene phase was carefully collected into test tubes and the absorbance of the fraction was read at $520 \mathrm{~nm}$ with a spectrophotometer (Shimadzu UV-1700). The proline concentration in the sample was determined from a standard curve using analytical grade L-proline and calculated on FW basis.

\section{The measurement of CAT activity}

The catalase (CAT, EC. 1.11.1.6) activity was assayed according to KATO and SHIMIZU (1987) by monitoring the consumption of $\mathrm{H}_{2} \mathrm{O}_{2}$ in a UV spectrophotometer (Shimadzu $\mathrm{UV}-1700$ ) at $240 \mathrm{~nm}$. The reaction mixture consisted of $0.2 \mathrm{~mL}$ enzyme extract, $1.5 \mathrm{~mL}$ phosphate buffer ( $\left.\mathrm{pH} 7.4,0.1 \mathrm{~mol} \mathrm{~L}^{-1}\right)$, and $1 \mathrm{~mL}$ distilled water. The reaction was started by adding $0.3 \mathrm{~mL} 0.1 \mathrm{~mol} \mathrm{~L}^{-1} \mathrm{H}_{2} \mathrm{O}_{2}$. Samples without $\mathrm{H}_{2} \mathrm{O}_{2}$ were used as blank. The decrease in absorbance was recorded every 30 seconds for $2 \mathrm{~min}$. The enzyme activity was expressed as mmol $\mathrm{H}_{2} \mathrm{O}_{2} \mathrm{~min}^{-1} \mathrm{mg}^{-1}$ protein by using the extinction coefficient of $40 \mathrm{mM}^{-1} \mathrm{~cm}^{-1}$ for $\mathrm{H}_{2} \mathrm{O}_{2}$. One CAT unit is defined as the amount of enzyme necessary to decompose $1 \mathrm{mmol}$ $\min ^{-1} \mathrm{H}_{2} \mathrm{O}_{2}$ under the above mentioned conditions.

\section{The measurement of PPO activity}

Polyphenol oxidase (PPO, EC 1.14.18.1) activity was assayed with 4-methylcatechol as a substrate according to the method described by ZAUBERMANN et al. (1991). The reaction mixture consisted of $0.5 \mathrm{~mL}$ diluted enzyme extract, $2 \mathrm{~mL}$ phosphate buffer $(\mathrm{pH} 7.0,0.1 \mathrm{~mol}$ 
$\mathrm{L}^{-1}$ ) and $0.5 \mathrm{~mL}$ of $100 \mathrm{mmol} \mathrm{L}^{-1} 4$-methylcatechol. The increase in absorbance at $410 \mathrm{~nm}$ at $25{ }^{\circ} \mathrm{C}$ was recorded every 30 seconds for $2 \mathrm{~min}$. The enzyme activity was expressed as changes in absorbance in $\mathrm{min}^{-1} \mathrm{mg}^{-1}$ protein.

\section{Protein determination}

Protein determination of the samples was made according to the Coomassie Brilliant Blue G250 method at $595 \mathrm{~nm}$ colorimetric wavelength (BRADFORD 1976).

\section{Disease assessment}

Disease symptom development was assessed 7, 11, 14, 17 and 21 DAI with a Fusarium yellow rating from 0 to 4 , in which $0=$ no lesions, $1=$ slight leaf chlorosis and necrosis, $2=$ vein clearing on outer leaflets, $3=$ yellowing and dropping of leaves, $4=$ dead plant. The plants were evaluated individually and the percentage of mean disease severity index (\% DSI) was calculated (TOWNSEND and HEUBERGER 1943).

\section{Statistical analyses}

The disease severity data were subjected to analysis with Levene's homogeneity of variance test then grouped by Duncan's multiple range test $(\mathrm{p}<0.05)$ contained in the SPSS software (SPSS Inc., Chicago, IL, USA). The experiment was conducted for each treatment from the scores of 60 plants (three replicates of 20 plants for each treatment) and repeated twice; representative results of two experiments for each treatment are presented in the results section.

\section{Results}

\section{The effect of ASM and FOM pretreatments on the reduction of Fusarium wilt symptoms}

In a previous study, the lowest disease ratings were detected at a time interval of $72 \mathrm{~h}$ between treatment and pathogen inoculation (ALTINOK 2009). From this work, this interval was taken into consideration in order to determine the disease development, histochemical study and enzyme assay experiments. Resistance induced in eggplant seedlings by ASM and FOM is presented in figure 1. Initial symptoms appeared seven days after inoculation as yellowing of the older leaves on ASM-, FOM-pretreated and positive control plants; the mean disease severity was $6.32 \%, 5.07 \%$ and $11.25 \%$, respectively. The systemic progress of the disease in control plants rapidly increased with time and by 21 DAI, most of the positive control plants showed severe wilting and eventually collapsed at the end of the experiment. Areas of browning were observed in the xylem of the infected stems. The pretreatment of eggplants with ASM and FOM before inoculation with Fomg did not inhibit pathogen penetration into the root tissues, but the progress of disease was much slower than those in only Fomg-inoculated plants. Non-inoculated seedlings (negative control plants) showed no symptoms and appeared healthy throughout the course of the experiment. At the end of the experiment, the mean disease severity in positive control plants reached $92.50 \%$ whereas in ASM- and FOM-pretreated plants it was $32.21 \%$ and $21.13 \%$, respectively (Fig. 1). 


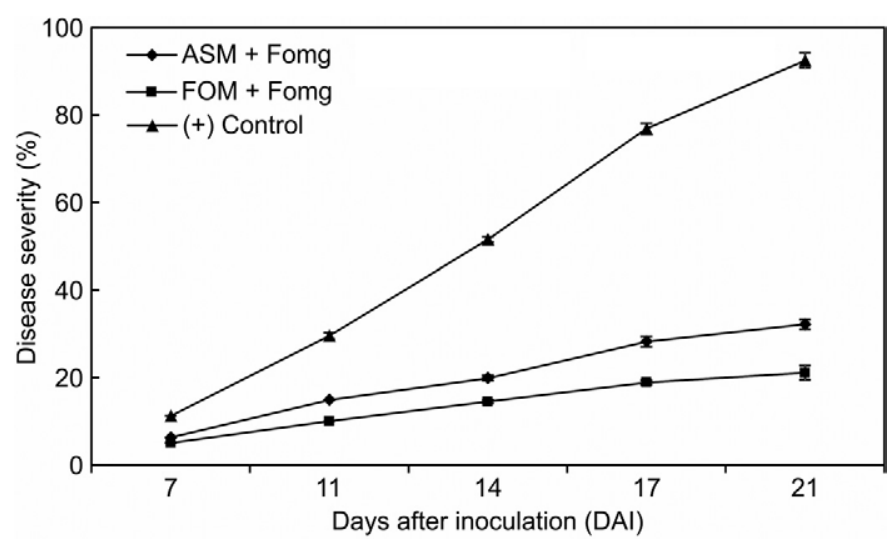

Fig. 1. Effect of ASM and FOM pretreatments on the severity of Fusarium wilt by Fomg.

\section{Accumulation of $\mathrm{H}_{2} \mathrm{O}_{2}$ at the reaction sites}

Light microscopy studies demonstrated that the applications of ASM and FOM enhanced a systemically induced resistance to Fomg infection in the susceptible eggplant cultivar. The localization and the timing of the accumulation of $\mathrm{H}_{2} \mathrm{O}_{2}$ to determine AOS accumulation was investigated using the technique of DAB staining. The tissue staining method used is based on the reaction of $\mathrm{H}_{2} \mathrm{O}_{2}$ with $\mathrm{DAB}$ to produce a dark brown precipitate at the reaction sites. In the present study, we demonstrated rapidly inducible responses including cell death after the attack of Fomg. In leaf epidermal cells, brown staining, an indicative sign of localized $\mathrm{H}_{2} \mathrm{O}_{2}$ production, was evident as early as $24 \mathrm{~h}$ after pretreatments with ASM and FOM (Figs. 2a, b). While no browning was detectable in non-infected epidermal cells, $\mathrm{H}_{2} \mathrm{O}_{2}$ accumulation in tissues stained with DAB was clearly localized to the sites of reaction in leaf epidermal cell walls (Figs. 2a, b). The accumulation of $\mathrm{H}_{2} \mathrm{O}_{2}$ was still evident after 11 days following pretreatments of ASM and FOM inducers (Figs. 2c, d).

\section{Callose deposition at reaction sites}

Histochemical localization of callose was previously described by BoUGOURD et al. (2000). In our study, the deposition of callose after pretreatments with ASM and non-host Fusarium oxysporum was closely associated with the accumulation of $\mathrm{H}_{2} \mathrm{O}_{2}$ (Figs. 3a, b). Callose was determined by fluorescence under UV light after aniline-blue staining as a marker of defense response after the pathogen attack. In mesophyll cells, callose accumulation was observed as blue autofluorescence after $24 \mathrm{~h}$ of the pathogen inoculation in ASMand FOM-pretreated plants (Figs. 3a, b). The mesophyll cells of the eggplant that had not been inoculated with the pathogen did not show any autofluorescence. The deposition of callose was still detectable after 11 days of pretreatments with ASM and FOM (Figs. 3c, d).

\section{Enzyme activities in ASM and FOM pretreated plants}

For the time convenience, the results obtained from the microscopy studies led us to perform biochemical analysis on 7, 14 and 21 DAI on test plants. When the accumulation of biochemical metabolites were considered, proline and $\mathrm{H}_{2} \mathrm{O}_{2}$ contents were found signifi- 


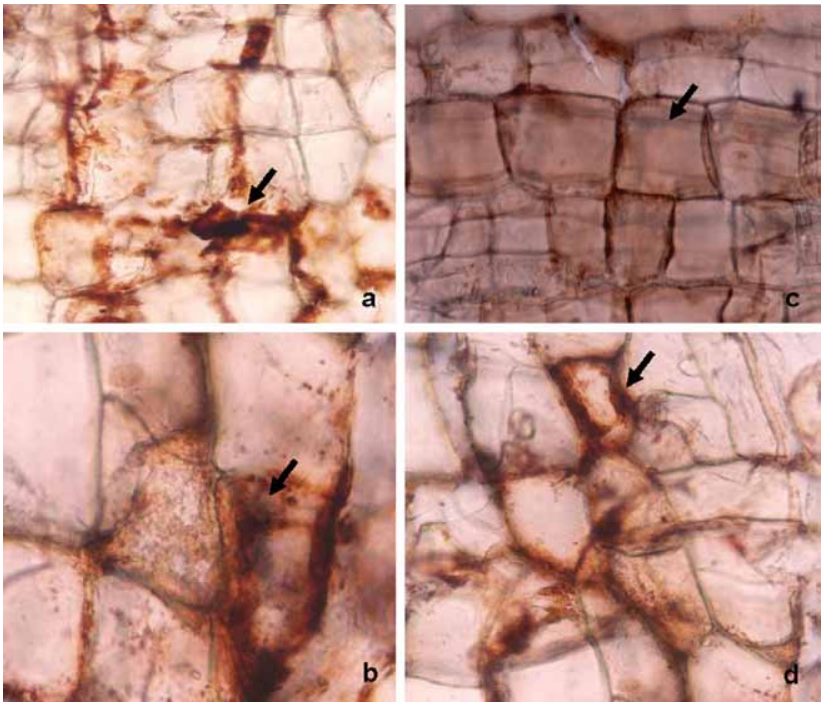

Fig. 2. Accumulation of $\mathrm{H}_{2} \mathrm{O}_{2}$ in the epidermal cells of ASM- and FOM-pretreated eggplant seedlings inoculated with Fomg; a - early accumulation $(24 \mathrm{~h})$ of $\mathrm{H}_{2} \mathrm{O}_{2}$ in the epidermal cells of eggplant following pretreatments of ASM; b - early accumulation (24 h) of $\mathrm{H}_{2} \mathrm{O}_{2}$ in the epidermal cells of eggplant following pretreatments of FOM; $\mathbf{c}$ - late accumulation (11 DAI) of $\mathrm{H}_{2} \mathrm{O}_{2}$ in the epidermal cells of eggplant following pretreatments of ASM; $\mathbf{d}$ - late accumulation (11 DAI) of $\mathrm{H}_{2} \mathrm{O}_{2}$ in the epidermal cells of eggplant following pretreatments of FOM.
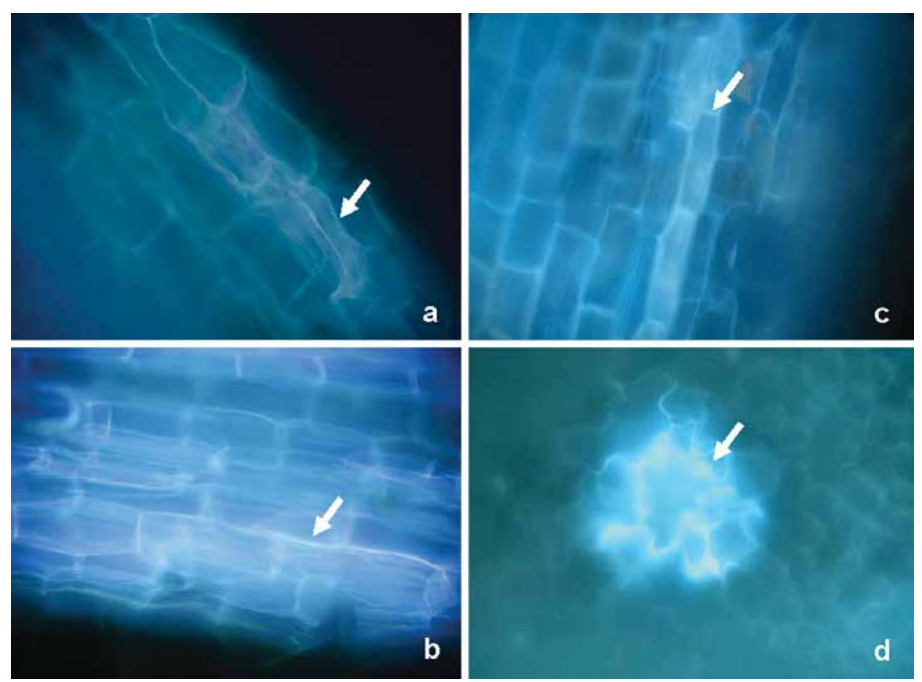

Fig. 3. Localization of callose in mesophyll cells of ASM- and FOM-pretreated eggplant seedlings inoculated with Fomg; a - early accumulation ( $24 \mathrm{~h}$ ) of callose in the mesophyll cells of eggplant following pretreatments of ASM; $\mathbf{b}$ - early accumulation $(24 \mathrm{~h})$ of callose in the epidermal cells of eggplant following pretreatments of FOM; $\mathbf{c}$ - late accumulation (11 DAI) of callose in the epidermal cells of eggplant following pretreatments of ASM; $\mathbf{d}$ - late accumulation (11 DAI) of callose in the epidermal cells of eggplant following pretreatments of FOM. 
cantly higher in ASM- and FOM-pretreated plants than those of Fomg-inoculated plants (Tab. 1, $\mathrm{p} \leq 0.05$ ). The accumulation of those metabolites was significantly higher when compared to control plants throughout the course of experiment indicating that ASM and FOM pretreated plants not only accumulated these metabolites earlier but also kept their level higher than those of control plants in which the accumulation of proline and $\mathrm{H}_{2} \mathrm{O}_{2}$ were also evident to a lower extent.

Tab. 1. Effect of ASM and FOM pretreatments on the biochemical activities of eggplants inoculated with Fomg.

\begin{tabular}{|c|c|c|c|}
\hline Days & $\mathrm{FOM}+$ Fomg & $\mathrm{ASM}+$ Fomg & (+) Control* \\
\hline \multicolumn{4}{|c|}{ Proline $\left(\mu \mathrm{mol} \mathrm{g}^{-1} \mathrm{FW}\right)$} \\
\hline 7 & $34.1 \pm 1.3^{\mathrm{b}^{* *}}$ & $49.6 \pm 4.4^{\mathrm{a}}$ & $30.1 \pm 1.9^{\mathrm{c}}$ \\
\hline 14 & $45.2 \pm 2.2^{\mathrm{a}}$ & $40.4 \pm 3.8^{\mathrm{ab}}$ & $35.5 \pm 2.6^{\mathrm{c}}$ \\
\hline 21 & $26.6 \pm 3.1^{\mathrm{ab}}$ & $30.5 \pm 2.9^{\mathrm{a}}$ & $16.9 \pm 1.8^{\mathrm{c}}$ \\
\hline \multicolumn{4}{|c|}{$\mathrm{H}_{2} \mathrm{O}_{2}\left(\mu \mathrm{mol} \mathrm{g}{ }^{-1} \mathrm{FW}\right)$} \\
\hline 7 & $30.1 \pm 7.3^{b}$ & $40.2 \pm 5.2^{\mathrm{a}}$ & $22.1 \pm 3.1^{\mathrm{c}}$ \\
\hline 14 & $35.2 \pm 5.2^{\mathrm{ab}}$ & $39.1 \pm 3.2^{\mathrm{a}}$ & $17.7 \pm 3.2^{\mathrm{c}}$ \\
\hline 21 & $25.1 \pm 4.1^{\mathrm{ab}}$ & $30.3 \pm 4.1^{\mathrm{a}}$ & $10.2 \pm 2.4^{\mathrm{c}}$ \\
\hline \multicolumn{4}{|c|}{ CAT $\left(\mu \mathrm{mol} \mathrm{min}{ }^{-1} \mathrm{mg}^{-1}\right.$ protein $\left.\mathrm{H}_{2} \mathrm{O}_{2}\right)$} \\
\hline 7 & $0.21 \pm 0.3^{\mathrm{b}}$ & $0.27 \pm 0.4^{\mathrm{a}}$ & $0.15 \pm 0.1^{\mathrm{c}}$ \\
\hline 14 & $0.15 \pm 0.1^{\mathrm{a}}$ & $0.17 \pm 0.1^{\mathrm{a}}$ & $0.06 \pm 0.1^{\mathrm{b}}$ \\
\hline 21 & $0.10 \pm 0.2^{\mathrm{a}}$ & $0.08 \pm 0.1^{\mathrm{a}}$ & $0.04 \pm 0.1^{\mathrm{b}}$ \\
\hline \multicolumn{4}{|c|}{$\mathrm{PPO}\left(\Delta \mathrm{OD}_{410} \mathrm{~min}^{-1} \mathrm{mg}^{-1}\right.$ protein $)$} \\
\hline 7 & $0.26 \pm 0.2^{\mathrm{a}}$ & $0.25 \pm 0.3^{\mathrm{a}}$ & $0.20 \pm 0.2^{\mathrm{b}}$ \\
\hline 14 & $0.11 \pm 0.2^{\mathrm{b}}$ & $0.14 \pm 0.3^{\mathrm{a}}$ & $0.08 \pm 0.2^{\mathrm{c}}$ \\
\hline 21 & $0.12 \pm 0.3^{\mathrm{a}}$ & $0.11 \pm 0.3^{\mathrm{ab}}$ & $0.09 \pm 0.1^{\mathrm{b}}$ \\
\hline
\end{tabular}

* Positive control plants were inoculated with Fomg.

** Data are means $( \pm$ SE) of at least three replicates. Means followed by different letters in lines are significantly different at $\mathrm{p} \leq 0.05$ as determined by Duncan's multiple range test.

When antioxidant enzymes were measured, CAT and PPO activities were also found significantly higher in ASM- or FOM-pretreated plants than those found in Fomg-inoculated plants (Tab. 1, $\mathrm{p} \leq 0.05$ ). The activities of the enzymes were significantly higher than those of positive control plants inoculated with Fomg throughout the course of the experiment although a general trend to decline was evident in the enzymes both in pretreated and treated plants. For example, the enzymatic activities in the second week declined and this trend carried on towards the end of experiment.

We demonstrated that the early production of $\mathrm{H}_{2} \mathrm{O}_{2}$ as well as the deposition of callose and the synthesis of the antioxidant enzymes and the stress metabolites such as proline in ASM- and FOM-pretreated plants played important roles in the early stages of defense against Fomg. The histochemical changes related with the synthesis of antioxidant enzymes 
and biochemical metabolites were well established and correlated. The results of the study showed that susceptible eggplants were enhanced with a systemically induced resistance to Fomg infection after pretreatments of ASM and FOM applications. ASM and FOM pretreatments resulted in HR and triggered the elaboration of histological barriers like callose and $\mathrm{H}_{2} \mathrm{O}_{2}$.

\section{Discussion}

In this study, the potential roles of ASM and FOM on the induction of resistance to Fomg were studied through biochemical and histological analysis. The microscopic observations indicated that the pretreatment of eggplants with ASM and FOM resulted in an increased rapid response and temporary production of AOS by the plant known as »oxidative burst « (MEHDy 1994, Low and MERIDA 1996). $\mathrm{H}_{2} \mathrm{O}_{2}$ from a potential oxidative cross-linking of the cell wall at the plant cell surface has been previously reported to be a characteristic response of plant cells to microbial elicitors or challenge with an avirulent pathogen (GRANT and LOAKE 2000). $\mathrm{H}_{2} \mathrm{O}_{2}$ has also been observed in cell walls of leaves undergoing HR. Similar observations have been highlighted by BENHAMOU and BELANGER (1998) in tomato; they suggested that the commercial use of Benzo-(1,2,3)-thiadiazole-7-carbothioic acid S-methyl ester $(\mathrm{BTH})$ would reduce the extent of fungal colonization in the plants, which was associated with a massive accumulation of structural barriers such as phenolic compounds. In our study, $\mathrm{H}_{2} \mathrm{O}_{2}$ and proline accumulation were quite effective in preventing the spread and further infection of the disease although the contents of proline and $\mathrm{H}_{2} \mathrm{O}_{2}$ declined towards the end of the experiment. The case in Fomg-inoculated plants followed the similar pattern with a low trend. The earlier accumulation of $\mathrm{H}_{2} \mathrm{O}_{2}$ is well correlated with the defense system. The increased production of radicals such as $\mathrm{H}_{2} \mathrm{O}_{2}$ is a common feature of defense responses to avirulent pathogens. For example, LEVINE et al. (1994) stated that the application of $\mathrm{H}_{2} \mathrm{O}_{2}$ not only increased the triggering of hypersensitive cell death, but also limited the spread of cell death by inducing cell protectant genes in surrounding cells. There are similar reports about an increased level of $\mathrm{H}_{2} \mathrm{O}_{2}$ contributing to the stimulation of disease resistance in plant; however, this high level was reduced by scavenging by antioxixant enzymes such as CAT and POD, which prevented the most harmful effects of excess $\mathrm{H}_{2} \mathrm{O}_{2}$ on cells (BAKER and ORLANDI 1995, CAO and JiANG 2006).

Histological events associated with cell death response involves the appearance of brown staining which is an indicative sign of $\mathrm{H}_{2} \mathrm{O}_{2}$ production in mesophyll cells undergoing pathogen attack (VANACKER et al. 2000). Histological events also involve the deposition of callose at reaction sites. For example, HAUCK et al. (2003) used histochemical staining with aniline blue followed by UV fluorescence microscopy to determine the callose at reaction sites after challenge with a hrcC mutant of Pseudomonas syringae pv. phaseolicola. BRAMMALl and Higgins (1988) reported that the response of tomato plants against $F$. oxysporum f. sp. radicis-lycopersici correlated with with genetic resistance. The thickening of host cell walls and the deposition of polymers such as $\beta-1,3$ glucan generally form appositions (papillae) in the cell wall (Bolwell and DAUDI 2009).

Although the activities of antioxidant enzymes did not show any significant differences in ASM and FOM pretreated plants, they were significantly higher than those of Fomg-inoculated group throughout the experiment. 
The increased concentrations in metabolites such as proline and $\mathrm{H}_{2} \mathrm{O}_{2}$ were in agreement with the increase of antioxidant enzymes. A similar case was also observed in the work of CAO and JIANG (2006), which reported a very strong correlation between the increment of peroxidase and $\mathrm{H}_{2} \mathrm{O}_{2}$ accumulation, which eventually increased phenolic compounds. These findings were also supported by the earlier work of SoYLU et al. (2003). They reported that the increases in POX activity and $\mathrm{H}_{2} \mathrm{O}_{2}$ were closely associated with progressive incorporation of phenolic compounds within the cell wall. In general, the reinforcement of the cell wall reduces susceptibility to wall-degrading enzymes secreted by pathogens. It is also possible that the diffusion of pathogen-derived toxins is restricted and forms a mechanical barrier to the penetration of fungal hyphae (DJEBALI et al. 2007).

In this study, evidence is provided that ASM-pretreatments could improve the condition of eggplants inoculated with Fomg by stimulating the many defense reactions, such as physiological and biochemical responses. Therefore, ASM-pretreatment could be used in practice against Fusarium wilt disease of eggplant caused by Fomg.

The current study with FOM on Fomg-inoculated plants also showed that the activation of plant resistance might possibly activate the genes that might in turn provide valuable information concerning fungal resistance mechanisms by using nonpathogenic Fusarium oxysporum formae speciales on eggplant. It is known that pathogenic strains display protective behavior on non-host plants against their specific Fusarium pathogens (AlABOUVETTE et al. 2009). In their capacity to protect plants against their pathogens, there is a great deal of diversity among soil-borne nonpathogenic strains of F. oxysporum, and some resistance-inducing strains have been isolated not only from soil, but also from the stems of healthy plants. As demonstrated by MiNERDI et al. (2008), one reason for the lack of pathogenicity in Fusarium strains is due to the associated ectosymbiotic bacteria complex that modulates the expression of pathogenicity genes. Although histochemical and enzymatic studies conducted here revealed the inductive effect of FOM against Fomg, FOM cannot conveniently be considered a biocontrol agent due to its pathogenic effect on other plant species. Therefore, further studies to elicit underlying mechanisms involved in the protective behaviors of pathogenic Fusarium species on non-host plants are necessary.

In conclusion, with the use of ASM and FOM, we showed that the increase in enzymatic activities corresponded to the accumulation of proline and $\mathrm{H}_{2} \mathrm{O}_{2}$ contents as well as $\mathrm{H}_{2} \mathrm{O}_{2}$ and callose accumulation microscopically in which all played significant roles and contributed to the increased levels of eggplant resistance to the attacking pathogen Fomg. It would be very important to determine the status and levels of pathogen-related (PR) proteins and enzymes such as glucanase and chitinase produced by the host plant as well as by the pathogen for their amounts and the specific activity (increased or decreased) would increase our insight into ASM- or FOM-mediated resistance. Although ASM appear not to have any antimicrobial characteristics, determining the production of PR proteins by the pathogen would enable us to gain a better insight under induced resistance conditions into whether this chemical could be used along with the other plant activators.

\section{Acknowledgements}

This study was supported by Research Fund of the Erciyes University. Project Number: FBA-0736. The authors are thankful to the late Dr. Yeter Canihos for her kind support; Dr. 
M. Kamberoglu and Dr. S. Soylu for kind assistance and Dr. Saim Ozdamar for laboratory facilities. The part of this study was carried out in the Central Science Laboratory of Harran University-Turkey.

\section{References}

Alabouvette, C., Olivain, C., Mighelo, Q., Christian, S., 2009: Microbiological control of soil-borne phytopathogenic fungi with special emphasis on wilt-inducing Fusarium oxysporum. New Phytologist 184, 529-544.

Alcazar, D. M., Egea, C., Espin, A., Candela, M. E., 1995: Peroxidase isoenzymes in defense response of Capsicum annuum to Phytophtora capsici. Physiological Plant Pathology 94, 736-742.

AltinOK, H. H., 2005: First report of Fusarium wilt of eggplant caused by Fusarium oxysporum f. sp. melongenae in Turkey. Plant Pathology, 54, 577.

AltinOK, H. H., 2009: Activation of systemic disease resistance by acibenzolar-S-methyl and a non-pathogen Fusarium oxysporum melonis (FOM) strain against Fusarium wilt disease in eggplant seedlings. Journal of Turkish Phytopathology 38, 21-32.

Altinok, H. H., CAN, C., 2010: Characterization of Fusarium oxysporum f. sp. melongenae isolates from eggplant in Turkey by pathogenicity, VCG and RAPD analysis. Phytoparasitica 38, 149-157.

Bates, L. S., Waldeen, R. P., Teare, I. D., 1973: Rapid determination of free proline for water stress studies. Plant and Soil 39, 205-207.

BAKer, C. J., Orlandi, E. W., 1995: Active oxygen in plant pathogenesis. Annual Review of Phytopathology 33, 299-321.

BENHAMOU, N., BÉLANGER, R. R., 1998: Benzothiadiazole-mediated induced resistance to $F u$ sarium oxysporum f. sp. radicis-lycopersici in tomato. Plant Physiology 118, 1203-1212.

Bolwell, G. P., DAUdi, A., 2009: Reactive oxygen species in plant-pathogen interaction. In: DEL Rio, L. A., Puppo, A. (eds.), Signaling and communication in plants, 113-133. Springer-Verlag, Berlin, Heidelberg.

Borden, S., Higgins, V. J., 2002: Hydrogen peroxide plays a critical role in the defense response of tomato to Cladosporium fulvum. Physiological and Molecular Plant Patho$\operatorname{logy} 61,227-236$.

Bougourd, S., MARrison, J., Haseloff, J., 2000: An aniline blue staining procedure for confocal microscopy and 3D imaging of normal and perturbed cellular phenotypes in mature Arabidopsis embryos. The Plant Journal 24, 543-550.

BRADFORD, M. M., 1976: A rapid and sensitive method for the quantitation of microgram quantities of protein utilizing the principle of protein-dye binding. Analytical Biochemistry $72,248-254$.

Brammall, R. A., Higgins, V. J., 1988: A histological comparison of fungal colonization in tomato seedlings susceptible and resistant to Fusarium crown and root rot disease. Canadian Journal of Botany 66, 915-925.

CAO, J., JiAnG, W., 2006: Induction of resistance in Yali pear (Pyrus bretschneideri Rehd.) fruit against postharvest diseases by acibenzolar-S-methyl sprays on trees during fruit growth. Scientia Horticulturae 110, 181-186. 
De Gara, L., De Pinto, M. C., Tommasi, F., 2003: The antioxidant system vis-a-vis reactive oxygen species during plant-pathogen interaction. Plant Physiology and Biochemistry 41, 863-870.

Djebali, N., Mhadhbi, H., Jacquet, C., Huguet, T., Aouani, M. E., 2007: Involvement of hydrogen peroxide, peroxidase and superoxide dismutase in response of Medicago truncatula lines differing in susceptibility to Phoma medicaginis infection. Journal of Phytopathology 155, 633-640.

Dikilitas, M., 2003: Effect of salinity and its interactions with Verticillium albo-atrum on the disease development in tomato (Lycopersicon esculentum Mill.) and lucerne (Medicago sativa and M. media) plants. PhD. Thesis, University of Wales, Swansea, UK.

Dikilitas, M., Kocyigit, A., Yigit, F., 2009: A molecular-based fast method to determine the extent of DNA damages in higher plants and fungi. African Journal of Biotechno$\log 8,3118-3127$.

Graham, T. L., Graham, M. Y., 1999: Role of hypersensitive cell death in conditioning elicitation competency and defense potentiation. Physiological and Molecular Plant Pathology 55, 13-20.

GRANT, J. J., LOAKE, G. J., 2000: Role of reactive oxygen intermediates and cognate redox signaling in disease resistance. Plant Physiology 124, 21-29.

HAMmERSCHMIDT, R., KUC, H. J., 1995: Induced resistance to disease in plants. Kluwer Academic Publishers, Dordrecht.

Hauck, P., Thilmony, R., He, S.Y., 2003: Pseudomonas syringae type III effector suppresses cell wall-based extracellular defense in susceptible Arabidopsis plants. Proceeding of National Academy of Sciences, USA, 100, 8577-8582.

Ishit, H., Tomita, Y., Horio, T., Narusaka, Y., Nakazawa, Y., Nishimura, K., Iwamoto, S., 1999: Induced resistance of acibenzolar-S-methyl (CGA 245704) to cucumber and Japanese pear diseases. European Journal of Plant Pathology 105, 77-85.

Jacobs, A. K., Lipka, V., Burton, R. A., Panstruga, R., Strizhov, N., Schulze-Lefert, P., FINCHER, G. B., 2003: An Arabidopsis callose synthase, GSL5, is required for wound and papillary callose formation. The Plant Cell 15, 2503-2513.

KATAN, T., 1999: Current status of vegetative compatibility groups in Fusarium oxysporum. Phytoparasitica 27, 51-64.

Kato, M. SHIMizU, S., 1987: Chlorophyll metabolism in higher plants VII. Chlorophyll degradation in senescing tobacco leaves: phenolic-dependent peroxidative degradation. Canadian Journal of Botany 65, 729-735.

LEE, D. H. KIM, Y. S., LEE, C. B., 2001: The inductive responses of the antioxidants enzymes by salt stress in the rice (Oryza sativa L.) Journal of Plant Physiology 158, 737-745.

Levine, A., Tenhaken, R., Dixon, R. Lamb, C., 1994: $\mathrm{H}_{2} \mathrm{O}_{2}$ from the oxidative burst orchestrates the plant hypersensitive disease resistance response, Cell 79, 583-593.

Low, P. S., MeridA, J. R., 1996: The oxidative burst in plant defense: function and signal transduction. Physiologica Plantarum 96, 533-542. 
MATTA, A., 1989: Induced resistance to Fusarium wilt diseases. In: TJAmos E. C., BeCKMAN, C. H. (eds.), Vascular wilt disease of plants. Springer-Verlag, NATO ASI Series 28, 175-196.

Mendy, M. C., 1994: Active oxygen species in plant defense against pathogens. Plant Physiology $105,467-472$.

Minerdi, D., Moretti, M., Gilardi, G., Berberio, C., Gullino, M. L., Garibaldi, A., 2008: Bacterial ectosymbionts and virulence silencing in a Fusarium oxysporum strain. Environmental Microbiology 10, 1725-741.

Nelson, A. J., Toussoun, T. A., Marasas, W. F. O., 1983. Fusarium species. An illustrated manual for identification. The Pennsylvania State University Press. University Park and London.

Nicholson, R. L., HAMmerschmidT, R., 1992: Phenolic compounds and their role in disease resistance. Annual Review of Plant Pathology 30, 369-389.

SoYLu, S., 2006: Accumulation of cell-wall bound phenolic compounds and phytoalexin in Arabidopsis thaliana leaves following inoculation with pathovars of Pseudomonas syringae. Plant Science 170, 942-952.

Soylu, S., Baysal, E., SOYlu, E. M., 2003: Induction of disease resistance by the plant activator, acibenzolar-S-methyl (ASM), against bacterial canker (Clavibacter michiganensis subsp. michiganensis) in tomato seedlings. Plant Science 165, 1069-1075.

Townsend, G. K., Heuberger, J. W., 1943: Methods for estimating losses caused by diseases in fungicide experiments. Plant Disease Reporter 27, 340-343.

Tsai, Y. C., Hong, C. Y., LiU, L. F., KAO, C. H., 2004: Relative importance of $\mathrm{Na}^{+}$and $\mathrm{Cl}^{-}$in $\mathrm{NaCl}$-induced antioxidant systems in roots of rice seedlings. Plant Physiology 122, 86-94.

VAnacker, H., CARVer, T. L. W., Foyer, H., 2000: Early $\mathrm{H}_{2} \mathrm{O}_{2}$ accumulation in mesophyll cells leads to induction of glutathione during the hyper-sensitive response in the barley powdery mildew interaction. Plant Physiology 123, 1289-1300.

Zauberman, G., Ronen, R., Akerman, M., Weksler, A., Rot, I., Fuchs, Y., 1991: Postharvest retention of the red color of litchi fruit pericarp. Scientia Horticulturae 47, 89-97. 